African Crop Science Journal by African Crop Science Society is licensed under a Creative Commons Attribution 3.0 Uganda License. Based on a work at www.ajol.info/ and www.bioline.org.br/cs DOI: http://dx.doi.org/10.4314/acsj.v26i2.4

\title{
PERCEIVED NUTRITION BENEFITS AND SOCIO-DEMOGRAPHIC FACTORS AFFECTING CONSUMPTION OF FOREST FOODS IN EASTERN AND SOUTHERN CAMEROON
}

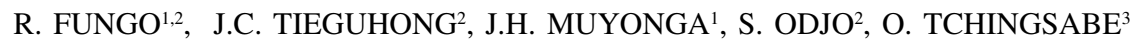 \\ and M. TCHATAT ${ }^{3}$
}

${ }^{1}$ School of Food Technology, Nutrition \& Bio-Engineering, Makerere University, P. O. Box, 7062, Kampala, Uganda

${ }^{2}$ Bioversity International Forest Genetic Resources Programme Via dei Tre Denari, 472/a 00057 Maccarese, Rome, Italy

${ }^{3}$ Institut de Recherche Agricole pour le Développement Yaoundé Cameroon. P. O. Box 2067, Yaoundé, Cameroon

Corresponding author: rfungom@yahoo.com

(Received 24 March, 2017; accepted 7 May, 2018)

\begin{abstract}
African forests act as sources of both plant and animal foods that provide significant amounts of nutrients and healthy boosting bioactive compounds. This study investigated the relationship between knowledge, perceptions and socio-demographic attributes towards consumption of forest foods. A total of 279 females in charge of decision making with respect to food preparation, were randomly selected from 12 villages in southern and eastern Cameroon, and interviewed using researcher administered questionnaires. Multivariate logistic regression analysis was used to identify the socio demographic factors and perceptions affecting consumption of forest foods. Baillonella toxisperma (African pearwood) (98\%), Irvingia gabonesis (bush mango) (81\%) and Trichoscypha abut (Mvout) (70\%) were identified as the most nutritious foods. Among the animal forest foods, bush meat (11\%) and Imbrasia spp. (edible caterpillars) (10\%) were identified as the most nutritious. Consumption of forest foods was higher among polygamous families and also positively related to length of stay in the forest area, as well as age of female respondents. Education had an inverse relationship with use of forest foods. Perception towards the nutritional value of forest foods were also found to positively influence consumption of forest foods. Since negative perceptions were found to influence consumption, there is need to invest in awareness campaigns to strengthen the current knowledge levels among the study population.
\end{abstract}

Key Words: Consumption, indigenous foods, perceptions

\section{RÉSUMÉ}

Les forêts africaines sont des réservoirs d'aliments végétaux et animaux fournissant des quantités importantes de nutriments et composés bioactifs stimulants naturels. La présente étude analyse la relation entre les connaissances, les perceptions et les caractéristiques sociodémographiques de la consommation des aliments issus des forêts. Un total de 279 femmes responsables du choix et de la préparation des aliments familiaux ont été choisis au hasard dans 12 villages du Sud et de l'Est du Cameroun, et interviewé à l'aide de questionnaires administrés par des chercheurs. L'analyse de régression multi-variée a été utilisée pour identifier les facteurs sociodémographiques et les perceptions qui affectent la consommation desdits aliments. Baillonella toxisperma (Moabi) (98\%), Irvingia gabonesis (mangue sauvage) (81\%) et Trichoscypha abut (Mvout) (70\%) ont été identifiés comme les aliments 
végétaux les plus nutritifs. Pour ce qui est des aliments forestiers d'origine animale, la viande de brousse (11\%) et Imbrasia spp. (chenilles comestibles) (10\%) ont été identifiés comme étant les plus nutritifs. La consommation des aliments issus des forêts était plus élevée parmi les familles polygames et positivement corrélée à la durée de séjour dans la zone forestière, ainsi qu'à l'âge des femmes interrogées. Le niveau d'éducation avait une relation inverse avec l'utilisation des aliments forestiers. La perception de leurs valeur nutritives avait également une influence positive sur leur consommation. Étant donné que les préjugés qui ont longtemps marqués ces aliments influencent négativement leur consommation, il est nécessaire de sensibiliser et de renforcer le niveau de connaissance des populations étudiée sur la valeur nutritive de ces produits.

Mots Clés: Consommation, aliments indigènes, perceptions

\section{INTRODUCTION}

Sub-Sahara African countries, including Cameroon, have high prevalence of undernutrition compared to recommended limits of $2 \%$ for stunting and $3 \%$ for underweight (CDHS, 2011; IFPRI, 2014). About 33 and $15 \%$ of Cameroonian children aged below five years, suffer from stunting and underweight (CDHS, 2011). The stunting and underweight rates are public health problems in Cameroon, because they are respectively 15 and 5 times higher, compared to the recommended limits for stunting and for underweight (IFPRI, 2014). The high malnutrition rates may be attributed to the growing negative perceptions towards traditional foods, resulting in changes in the food systems and dietary patterns (IFPRI, 2014; FAO, WFP and IFAD, 2014).

A shift to simplified and monotonous diets, from the diversified traditional diets has resulted in increased consumption of staple foods, and a decrease in the consumption of traditional foods including forest foods that are abundantly and locally available within the region (Keller et al., 2006; Frison et al., 2006; Pingali, 2007; Penafiel et al., 2011). Negative perceptions towards forest foods have been documented among rural communities in South Africa (Dweba and Mearns, 2011) and in Togo (Akpavi et al., 2008). The adoption of western lifestyle has also been reported to be associated with the reduction in indigenous knowledge on the use and preparation of several traditional African food dishes (Maundu, 1996; Akpavi et al., 2008).
Nutrient composition studies of forest foods reveal that some forest food species of plants and animals origin have high contents of essential nutrients and bioactive compounds (Maundu, 1996; Akpavi et al., 2008; Blaney et al., 2009; Dweba and Mearns, 2011; Penafiel et al., 2011; Powell et al., 2013; Fungo et al., 2015). A recent study in south and eastern Cameroon revealed that there is considerable potential for forest foods to contribute to intake of essential nutrients among consumers of these foods (Fungo et al., 2016a). In Gabon, forest foods contribute $36 \%$ of total vitamin A and $20 \%$ of iron (Blaney et al., 2009), while in Tanzania 31\% of RAE (vitamin A) and 19\% of iron can be accessed in forest diets (Powell et al., 2013). Furthermore, traditional forest foods are usually referred to as "food for the poor" by the educated and a section of the elite urban residents in Africa, resulting in their neglect (Akpavi et al., 2008; Dweba and Mearns, 2011; Fungo et al., 2016b).

These findings are corroborated by case studies in DR Congo among the forest dependent communities of Kisangani (Termote et al., 2012), the Guiziga tribe in Cameroon (Hamawa, 2013) and populations adjoining Lama Forest reserve in Benin (Boedecker et al., 2014). Despite these communities having access to abundant nutrient rich traditional forest foods, under-nutrition and food insecurity is rampant among them. However, there is paucity of information on how perceptions towards the health and nutritional benefits from forest foods and sociodemographic factors affect consumption of the forest foods. This study therefore, explored 
the relationship between knowledge, perceptions and socio-demographic attributes towards consumption of forest foods.

\section{METHODOLOGY}

Study area description. The study was conducted in two sites, including one from the East and the other from the South of Cameroon. The geographical coordinates for eastern site are 3.98 longitudinal and 13.18 latitude and southern site are 2.93 longitudinal and 11.16 latitude (Noutcheu et al., 2016). The Eastern site has a population of about 25,783 people consisting of three indigenous ethnic groups; the Kako, the Pol and the Baka pygmies, living in 41 villages (Medinof, 2004). In the southern site, the population is estimated at 79,353 consisting of almost one major ethnic group the Bulu, living in 29 villages (Enviro Consulting, 2009).

Selection of study districts, villages and households. Selection of study districts, villages and households was done using a three-stage cluster sampling technique composed of one stage of purposeful selection and two stages of randomisation. The first stage involved purposefully selecting districts from both sites on the basis of communities in the districts relying on the forests as a source of livelihoods and their accessibility. The second and third stages, involved randomly selecting villages that are easily accessible within the chosen two districts and households within the selected villages. As a result of a higher ethnic diversity in the Eastern site, the study was conducted in seven villages including Kouedjina (10 households), Kagnol III (17 households), Ndembo (10 households), Petit Pol (44 households, Melambo (23 households), Nkolbikon (16 households) and Bonando (34 household). In the south, with only one ethnic group, the study was conducted in five villages, including Ngon (21 households), Bissam (39 households), Ondondo (39 households), Methyikpwale (20 households) and Meyos (6 households). Two Research Assistants (RAs) who had grown up in the villages of the two study sites were recruited and trained for acquaintance with the interview schedules. The two RAs aided in interpreting the cultural norms and meanings of local comments expressed by respondents during the interview.

Household sample. A total of 276 households, in the two sites was calculated using Fisher's (Fisher, 1998) formula below:

$n=\frac{t^{2} \times p(1-p)}{m^{2}}$

Where:

$\mathrm{n}=$ required sample size, $\mathrm{t}=$ confidence level at $95 \%$ (standard value of 1.96) $\mathrm{p}=9.9 \%$ estimated proportion of population depending on the forests with regard to the total population (Chao, 2012) and $\mathrm{m}=$ margin of error at 5\% (standard error of 0.05).

To cater for drop-outs during the data collection process, the number of households per site was increased by $5 \%$. However, data were captured from a total of 279 households in the two sites, representing a response rate of $92 \%$. This sample size was about $40 \%$ of total number of households in each village. The inclusion and exclusion criterion of households in the present study, included (i) households that depended on the forests for food, (ii) households with members that were residents of the target areas, and (iii) households with respondents who were healthy at the time of recruitment.

Ethical approval and consent. Prior to contact with the study populations, the study proposal was presented to the Regional Forestry Office and the Regional Health Office in the two study regions. During the meetings, a written permission was sought to carry out the study. In addition to the clearance by the Regional Forestry and Health Offices, further 
permission was sought from the political leaders at district and village levels to assist the study gain the cooperation of the household respondents. All standards on human and health care ethics outlined in the Helsinki Declaration (World Medical Association Declaration of Helsinki, 2001) were adhered to.

Data collection. Interviews took place at homes of the respondents during the months of May and June 2012, with spouses of households. Also, women who were household heads and had dependents were interviewed. Women were interviewed because they are vital in the decision making with respect to food preparation (Becquey et al., 2009).

Data collected included household sociodemographics, knowledge of nutritious and healthful forest food species, uses, perceptions and knowledge of health benefits of forest foods. Prior to interviews, questionnaires were pre-tested and adapted to the local context of Cameroon.

The socio-demographic questions included age, sex, occupation and education level of the respondent and material used to construct household houses. The healthful and nutritionally important forest foods were identified and listed by the respondents. Respondents were also asked (i) if they knew that malnutrition can lead to ill health, and (ii) if they were aware that forest foods were nutritious and healthful.

Five questions were used to assess the level of perceptions of the respondents (Table 3), towards the importance of forest foods to their health. Respondents had an option of using a narrative scale that explored the respondents' agreement, disagreement or uncertainty. Practices related to use of forest foods (Table 4) were assessed using four questions, with three questions being open-ended, while one question on number of times of preparing forest foods having response options of 'none', 'once', '2-3 times' and 'more than 4 times'. Computation of knowledge, perception and practices for each question, was done as the proportion of respondents who gave an affirmative answer.

Data analysis. All data were analysed using the Statistical Package for the Social Sciences (SPSS) version 21 (SPSS Inc., Chicago Ill, USA). The Mean values were computed for continuous variables; while proportions were computed for the categorical variables. Multinomial logistic regression analysis was performed to identify the independent factors (Table 5).

Multinomial regression analysis was performed based on previous studies (Kimiywe et al., 2007; Dweba and Mearns, 2011), where two age groups of (i) $<46$ years which is considered to be within the reproductive age for women who are energetic but constrained with the burden of baring children, and (ii) $>46$ years, which is beyond the reproductive age who have time but with diminished energy reserves, to adequately cater for their families were created, for comparison purposes (Onarheim et al., 2016).

The level of significance for inclusion of variables in the logistic regression models was set at $\mathrm{P}<0.05$, in order to have findings comparable to similar previous studies (Chen et al., 2003; Serra-Majem et al., 2007; Bojorquez et al., 2015). Associations between the independent and dependent variables were expressed as odds ratios. A confidence interval of $95 \%$ was used to determine significant differences in all statistical analyses.

\section{RESULTS}

Respondent characteristics. Average age of respondents was 44 years. The majority of respondents had attended or completed primary school (64\%), and more than half (56\%) had 5-9 dependents (Table 1). About $75 \%$ of the households, were natives of the study area, and therefore the knowledge and perception they possessed could be considered 
TABLE 1. Household socio-demographic characteristics in Eastern and Southern Cameroon

\begin{tabular}{ll}
\hline Household characteristics & $n$ \\
\hline $\begin{array}{l}\text { Age of respondent } \\
\text { Average age }\end{array}$ & 277
\end{tabular}

Minimum

Maximum

Education of respondent

277

No formal education

Primary class 1-4

Completed primary school

Completed secondary form 4

Completed University

n Respondents

$(\%)^{\dagger}$

Household size

Low (1- 4)

Medium (5 - 9)

High $(10-14)$

Period of stay within the

study area

$<12$ months

1-2 years

$>2<5$ years

$>5<10$ years

$>10$ years

Place of residence in the

study area

Same area (outskirts of forest)

Another forest (not current

forest site)

Another part of this forest

Inside the forest

Ownership of house

Owned

No ownership (user rights)

Rented

Provided by employer

Roofing of house

Iron-sheets

Tree branches and leaves

Grass thatch

Tiled

$43.7 \pm 14.2$

17.0 Energy source for cooking

82.0

4.7

21.3

42.2

28.9

2.9

3.6

7.3

6.2

80.7

77

House walls

Timber

Concrete or brick walls

31.8

15.9

Harvest tree branches
TABLE 1. Contd.

\begin{tabular}{lcc}
\hline Household characteristics & $\mathrm{n}$ & $\begin{array}{c}\text { Respondents } \\
(\%)^{\dagger}\end{array}$ \\
\hline Mud walls & & 4.3 \\
Grass & & 0.4 \\
& & \\
Energy source for cooking & 276 & \\
Fire wood & & 97.2 \\
Charcoal & & 2.2 \\
Paraffin stoves & & 0.8 \\
& \\
Source of energy for lighting & 277 & \\
Kitchen firewood & & 66.9 \\
Electricity & & 30.0 \\
Paraffin lanterns & & 3.3 \\
& & \\
Water source & 276 & 62.0 \\
Pond & & 17.0 \\
River & & 10.5 \\
Public spring & & 9.1 \\
Bore hole & & 1.6
\end{tabular}

Economic activities of forest $\quad 279$

dependent communities

Farming

Hunting and gathering forest $\quad 28.0$

foods

Trading $\quad 7.6$

Artisan works $\quad 5.3$

Salaried employment $\quad 3.2$

Artisanal logging \&informal $\quad 2.9$

timber trading

Pension 1.1

Casual employment $\quad 0.4$

$\mathrm{n}=$ Number of households. ${ }^{\dagger}=$ Percentage of total number of household 
local. Despite being forest-dependent communities about half (52\%) of the households also practiced farming.

Nutrient rich forest foods. Fruits of Baillonella toxisperma (African pearwood) were listed by $98 \%$ female respondents, as the most important nutrient-rich forest foods (Table 2). These were followed by Irvingia gabonesis (Bush mango), Elaeis guineensis (palm oil), Trichoscypha abut (Mvout) and Ricinodendon heudelotii (Djansang). Among animal foods collected from forests, bush meat ('gibier') was the most consumed (11\%), followed by Imbrasia spp. (edible caterpillars), $(10 \%)$, Achatinidae spp. (snails) $(6 \%)$ and Termitoidae spp. (termites) (3\%).
Perceptions towards the health benefits. A considerable proportion of respondents $(>50 \%)$ generally expressed positive perceptions towards some specific benefits accrued from consuming forest foods, with most $(61 \%)$ expressing safety concerns and health disorders related to malnutrition (Table $3)$. The least (10\%) expression of positive perception was registered in two sets of respondents. This included one set of respondents who agreed that bush meat was nutritionally important and the second set of respondents who believed vitamin A and iron content in forest foods is adequate to maintain a healthy lifestyle.

TABLE 2. Forest foods identified to be of highly nutritional value by forest dependent communities in Southern and Eastern Cameroon

\begin{tabular}{lcc}
\hline Scientific name & Number of female respondents & Respondents (\%) \\
\hline Baillonella toxisperma (African pearwood) & 273 & 97.8 \\
Irvingia gabonesis (Bush Mango) & 226 & 81.0 \\
Trichoscypha abut (Mvout)* & 70 & 25.2 \\
Elaeis guineensis (Palm oil) & 54 & 19.3 \\
Ricinodendon heudelotii (African wood-oil nut) & 41 & 14.6 \\
Bush meat (Gibier) & 30 & 10.9 \\
Funtumia Africanum (Wild spinach) & 30 & 10.9 \\
Imbrasia spp. (Caterpillars) & 27 & 9.7 \\
Agaricus bisporus (Mushrooms) & 23 & 8.4 \\
Achatinidae spp. (Snails) & 17 & 5.9 \\
Coula edulis (African walnut) & 14 & 5.0 \\
Ampelocissus spp. (Wild grape) & 10 & 3.7 \\
Maranthacae spp. (Ngong)* & 10 & 3.7 \\
Miel (Honey) & 7 & 2.5 \\
Dacryodes edulis (Bush butter tree) & 7 & 2.5 \\
Termites & 7 & 2.5 \\
Rhynchophorus phoenicis (Palm weevil) & 3 & 1.2 \\
Cola acuminata (Cola) & 3 & 1.2 \\
Dioscorea spp. (Wild yams) & 3 & 1.2 \\
Angylocalyx talbotii (Nkana)* & 3 & 1.2 \\
Afrostyrax lipidophyllus (Wild onion) & 3 & 1.2 \\
\hline
\end{tabular}

* Forest foods without an English common name. Trichoscypha abut is a timber producing tree with bright purple nutritious fruits sought for food (African Plant Database, 2013). The fruits of Maranthacae spp. are harvested and consumed as condiments. Cola acuminate, has caffeine containing fruits that are consumed as stimulants (Burdock et al., 2009). Angylocalyx talbotii is a species of a legume in the Fabaceae family, whose leaves are consumed (African Plant Database, 2013). 
TABLE 3. Perceptions towards forest foods consumption in Eastern and Southern Cameroon

\begin{tabular}{lccc}
\hline Perceptions aspects assessed* & Agree (\%) & Disagree (\%) & Uncertain (\%) \\
\hline Forest foods are nutritious and healthy & 31.2 & 39.2 & 29.7 \\
Nutritionally rich & 30.9 & 29 & 40 \\
Good sources of health boosting nutrients for health & 36.2 & 39.1 & 24.7 \\
Not good for health & 15.3 & 60.7 & 24.0 \\
Good for eye sight & 52.6 & 4.7 & 42.7 \\
Bush meats contribute more to increase in height in & 10.0 & 64.9 & 25.1 \\
comparison to forest plants & & 54.1 & 35.5 \\
Can substitute Vitamin A and iron supplements & 10.4 & & \\
\hline
\end{tabular}

*: Assessed 279 female respondents

Consumption of forest foods. About $40 \%$ of the respondents consumed forest foods daily for their meals (Table 4). Among the respondents that consumed forest foods, $85 \%$ of households reported eating forest foods once to more than 4 times daily. Preparation of household meals was exclusively done by women $(96 \%)$; and most respondents $(77 \%)$ expressed that women were responsible for making decisions regarding choice of foods to be consumed for household meals.

About $69 \%$ of the respondents mentioned that they processed $B$. toxisperma into edible oil, which is a more valuable product for household consumption and income security. A minority of respondents mentioned processing other valuable forest foods, notably I. gabonesis (9\%), E. guineensis 1 (7\%), $R$. heudelotii (0.4\%) and P. macrophylla (0.4\%).

Factors affecting consumption of forest foods. Logistics regression analysis revealed that female respondents aged 46 and above, were 1.4 times more likely to prepare forest foods (OR=1.37 95\% CI 0.60 to 3.13), than respondents aged below 46 (Table 5). On the other hand, education had an inverse relationship with use of forest foods. Illiterate respondents were 6.3 folds more likely to prepare forest foods $(\mathrm{OR}=6.2695 \%$ CI 0.60 to 18.09) than respondents who did not complete primary school, those who completed
TABLE 4. Practices of preparing forest foods and forest foods processed in Eastern and Southern Cameroon.

Practices and processed

Respondents forest foods $(\%)$

Times forest foods are prepared per day $\quad(n=109)$

$\begin{array}{ll}\text { None } & 14.7 \\ \text { Once } & 12.8 \\ 2-3 \text { times } & 45.0 \\ \text { More than 4 times } & 27.5\end{array}$

Who decides type of food to prepare $\quad(n=109)$

Father $\quad 21.1$

Mother $\quad 77.1$

Children (girl) $\quad 0.9$

Grand mother $\quad 0.9$

Member of household who prepares $\quad(n=109)$

foods

Father $\quad 2.5$

Mother $\quad 96.4$

Children (girl) $\quad 0.7$

Grand mother $\quad 0.4$

Forest foods processed into products? $\quad(n=279)$

Baillonella toxisperma (Moabi) $\quad 68.8$

Irvingia gabonesis (Bush Mango) $\quad 9.3$

Elaeis guineensis (Palm Oil) $\quad 6.9$

Ricinodendon heudelotii (Djangsang) $\quad 0.4$

Pentaclethra macrophylla Benth (Ebaye) $\quad 0.4$

$\begin{array}{ll}\text { None } & 14.3\end{array}$ 
TABLE 5. Logistic regression analysis on the socio demographic factors and perceptions associated with the consumption of forest foods in Eastern and Southern Cameroon

\begin{tabular}{llll}
\hline Consumption of forest foods* & Odds ratio & $-95 \%$ CI & P valu
\end{tabular}

\section{Socio demographic characteristics}

Age

$<46$ years

$>46$ years

1 (reference)

$\begin{array}{llll}1.37 & 0.6 & 3.13 & 0.04\end{array}$

\section{Education}

University trained

No formal education

Primary school (class 1-4)

Completed primary school

Few years in secondary school

Odds ratio

- $95 \% \mathrm{CI}$

value

Completed secondary school

1 (reference)

$\begin{array}{llll}6.26 & 0.6 & 18.09 & <0.001 \\ 3.04 & 0.78 & 11.76 & <0.001 \\ 2.51 & 0.69 & 9.13 & <0.001 \\ 2.67 & 0.69 & 10.33 & <0.001 \\ 1.37 & 0.26 & 7.09 & <0.001\end{array}$

\section{Marital status}

Single adult

Married (polygamous)

Married (monogamous)

1 (reference)

$\begin{array}{llll}6.96 & 0.13 & 37.24 & 0.007\end{array}$

$\begin{array}{lll}5.16 & 0.14 & 18.56 \quad<0.001\end{array}$

Period of stay in area by respondent

$<12$ months

$1-2$ years

$>2<5$ years

$>5$ years

1 (reference)

$<0.001$

$1.31-0.42$

$4.06<0.001$

6.03

2.13

$16.9<0.001$

Attitudes/perceptions

7.64

1.92

30.44

$<0.001$

Forest foods are nutritious

Do not know

Correct

Not correct

1 (reference)

$\begin{array}{llll}4.02 & 0.59 & 5.04 & 0.04\end{array}$

$\begin{array}{llll}1.61 & 0.17 & 2.26 & <0.001\end{array}$

Poor nutrition can lead to disease

Do not know

Correct

1 (reference)

Not correct

$\begin{array}{llll}1.11 & 0.27 & 4.59 & <0.001 \\ 0.87 & 0.35 & 2.18 & 0.004\end{array}$

Have health boosting nutrients

Uncertain

Agree

1 (reference)

Disagree

$\begin{array}{llll}6.43 & 1.22 & 33.88 & <0.001 \\ 2.5 & 1.02 & 62.61 & <0.001\end{array}$

Not good for health

Uncertain

Agree

Disagree

1 (reference)

$\begin{array}{llll}3.76 & 0.45 & 31.44 & 0.002 \\ 1.02 & 0.549 & 1.91 & <0.001\end{array}$

For a good eye sight

Uncertain

Agree

1 (reference)

Disagree

$\begin{array}{llll}3.09 & 1.69 & 5.66 & <0.001 \\ 1.2 & 0.37 & 4.07 & <0.001\end{array}$


TABLE 5. Contd.

\begin{tabular}{lllll}
\hline Consumption of forest foods* & Odds ratio & & P Value \\
\hline Bush meat have nutrients that lead to growth & & & \\
Uncertain & 1 (reference) & & \\
Agree & 8.77 & 0.46 & 16.75 & $<0.001$ \\
Disagree & 3.69 & 0.45 & 7.13 & $<0.001$ \\
Can substitute vitamin A and iron supplements & 1 (reference) & & \\
Uncertain & 12.74 & 1.74 & 35.82 & $<0.001$ \\
Agree & 5.63 & 1.25 & 23.96 & $<0.001$ \\
Disagree & & & & \\
Practices & & & \\
Who prepares food for children? & 1 (reference) & & \\
Father & 2.5 & 0.1 & 62.61 & 0.014 \\
Children (daughters) & 1.218 & 0.59 & 11.01 & $<0.001$ \\
Grand mother & 6.43 & 1.22 & 33.88 & $<0.001$ \\
Mother & & & \\
Who decides what food to prepare? & 1 (reference) & & \\
Father & 0.54 & 0.1 & 8.59 & $<0.001$ \\
Children (daughters) & 1.17 & 0.86 & 4.08 & $<0.001$ \\
Grand mother & 12.65 & 0.59 & 26.71 & $<0.001$ \\
Mother & & &
\end{tabular}

*Dependent variable (consumption of forest foods) tested against independent variables (household demographic factors, perceptions and attitudes) that were controlled as indicated in Table 4 . CI= confidence interval

primary school or secondary school. Regarding the relationship between knowledge and consumption of forest foods, the analysis revealed that consumption of forest foods significantly increased by 4 times $(\mathrm{OR}=4.02$ $95 \%$ CI 0.59 to 5.04 ) among respondents who knew that forest foods were nutritious and by 1.1 times among (OR=1.11 95\% CI 0.27 to 4.60) those that knew that poor nutrition can lead to health disorders related to inadequate intake of nutrients and death.

Polygamous households were more than 6 times $(\mathrm{OR}=6.9695 \% \mathrm{CI} 0.13$ to 37.24$)$ likely to prepare forest foods, than families that were monogamous (Table 5). Results further indicated that consumption of forest foods increased with period of stay in an area. The multivariate analysis further revealed that respondents who expressed positive perception towards the health and nutrition benefits of consuming forest foods were more likely to prepare and consume forest foods. The highest registered likelihood of about 13 times $(\mathrm{OR}=12.7495 \% \mathrm{CI} 1.74$ to 35.82$)$, was registered among respondents who agreed that forest foods can substitute for vitamin and iron supplements (Table 5). Mothers were about 12 times more likely to prepare forest foods $(\mathrm{OR}=12.6595 \%$ CI 0.59 to 26.71$)$ than their daughters and grandmothers.

\section{DISCUSSION}

Nutrient rich forest food species. Out of the 21 forest foods perceived by respondents as most healthful and nutritionally important, 16 were plant based; while 5 were wild animal sourced foods. Among the plant forest foods, the oil producing foods ( 9 species) were identified as the most important nutrient rich and healthful forest foods. Of the nine oil producing species, five were among the most 
nutrient rich overall including; Baillonella toxisperma (African pearwood), Irvinga gabonensis (bush mango), Trichoscypha abut (Mvout), Elaeis guineensis (palm oil) and Ricinodendon heudelotii (African wood-oil nut).

The high demand for oil producing fruits can be attributed to their high market value in Cameroon and neighbouring countries, such as Nigeria and Gabon (Awono et al., 2009). In these countries the kernels are processed using traditional methods, to produce edible oil that is used in household food preparation, while the surplus is sold for income security (Levang et al., 2014). The identified oil producing forest foods in the present study are also consumed as fruits. For example, the fruits of I. gabonesis are popular among children because of their attractive sweet yellow pulp, as result of their high $\beta$-carotene nutrient content (Ejiofor et al., 1987; Fungo et al., 2015). The multipurpose use of oil producing forest plant foods in Cameroon can be an important reason for their conservation.

Among animal forest foods, bush meat, Imbrasia spp. (Caterpillars) and Achatinidae spp. (edible snails) were the most consumed (Table 2). Bush meat provides considerable amounts of proteins and essential micronutrients to vulnerable communities residing in and adjacent to forests in (Keegan, 1986; Kopper et al., 1993). Conservation studies in Cameroon reveal that non-respect of the wildlife legislation to protect wild life, has resulted in unsustainable hunting of wild animals for food (Cerutti and Tacconi, 2006; Nasi et al., 2011; Fungo, 2016). The major identified forest foods in Cameroon in the present study, are similar to studies reported in Cameroon and other Congo Basin countries (for example, Tacconi et al., 2003; Nasi et al., 2011; Termote et al., 2012; Hamawa, 2013; Boedecker et al., 2014).

Perceptions towards the health benefits of forest foods. From our results, about a half to about two thirds of the forest dependent communities, displayed positive perceptions towards the importance of consuming forest foods in order to maintain a good eye sight and the overall health (Table 3). Consumption of forest foods is positively related to the recognition of these foods by communities, as healthy diets (Table 3 ). Forest foods were consumed because they had health boosting nutrients, good for eye sight and could substitute for vitamin A and iron supplements.

The relatively higher rates of positive perceptions towards the health benefits of forest foods in the present study may be attributed to the respondents being in possession of health and nutrition information. In Cameroon, health and nutrition information messages are disseminated to rural mothers and guardians at health centres during the prenatal and post-natal visitations and vitamin and mineral supplementation days (CDHS, 2011). Some of the respondents possessed negative perceptions towards specific health and nutrition benefits when forest foods were consumed. For example, only $10 \%$ of the respondents in the present study displayed positive perceptions towards bush meat as having essential nutrients to permit growth among children (Table 3). This can be attributed to some rural communities in Cameroon, lacking detailed specific knowledge concepts about the health and nutritional benefits of forest foods. There is need to invest in advocacy village level community nutrition education programmes aimed at imparting positive perceptions of forest populations by improving their knowledge base with respect to the health and nutrition benefits of forest foods.

\section{Factors that affect consumption of forest}

foods. The $40 \%$ fraction of the female respondents that used forest foods for household meals in the present study (Table 4) was higher than what has been documented in previous findings. For example, in DR Congo about $30 \%$ residents of Kisangani and Turumbu areas prepared household meals with 
forest foods (Termote et al., 2012). The present study using the logistic regression analysis, positively associated the practice of consuming forest foods with respondents aged 46 and above, lowly educated respondents, polygamous households, women making decisions on which food to prepare and those who had longer stays in the study area.

Education level of respondents was inversely related to consumption of forest foods in the present study (Table 5). The present study concurs with previous studies which revealed that educated Kenyans, South Africans and Ugandans who earn more than the less educated, viewed traditional and indigenous foods as food for the poor; hence having less preference to consume traditional and indigenous African foods as compared to the western processed foods (Tabuti et al., 2004; Kimiywe et al., 2007; Dweba and Mearns, 2011). In comparison with the consumption levels, of the uneducated in Kenya, South Africa and Uganda, educated populations have been found to consume less of wild and indigenous fruits and vegetables (Oniang'o et al., 2003; Pelto et al., 2004; Tabuti et al., 2004). The educated Kenyans, South Africans and Ugandans are exposed to influences of urbanisation and western lifestyles, which lead to adopting negative perceptions towards local and indigenous African foods (Haddad, 2003; Pingali, 2007). This has resulted in the African elites moving away from the more diverse traditional and indigenous diets with strong cultural identity, to monotonously processed imported and sometimes unhealthy diets.

An increase in the age of the respondents positively influenced the preparation of forest foods (Table 5). The older the household head the better the levels of perceptions towards nutrition and health benefits of forest foods. The elderly have a lifetime experiences that have shaped their individual values, habits and preferences, motivated by convenience, sensory appeal and perceived importance of traditional foods to health. These findings relating age with consumption of forest foods are similar to findings elsewhere (Pelto et al., 2004; Dweba and Mearns, 2011).

Consumption of forest foods in the present study was considerably higher when mothers prepared household meals, than their daughters (Table 5). Collection and preparation of wild and indigenous forest foods from the natural environment, is an activity that is mostly done by spouses of households. Children, especially daughters in rural settings, learn from their mothers which traditional and indigenous foods are nutritionally superior and appropriate to prepare. As opposed to rural women who focus on gathering forest foods to feed their households, household heads in urban areas in Cameroon and elsewhere in Africa engage more in activities that generate higher income used to buy more of the imported refined food than forest foods (Parsons, 1993; Rensberg et al., 2004; Hart and Vorster, 2006; Hamawa, 2013; Levang et al., 2014).

A significant positive association was found between respondents' who expressed positive perceptions towards health and nutrition benefits of forest foods, with consumption and preparation of forest foods (Table 5). Specifically, the logistic regressive odds in Table 5 reveal that consumption of forest foods, was more than 9, 4, 6 and 3 times, more likely to occur, among respondents who agreed with statements; "consumption of bush meat can make a child taller", "forest foods are nutritious", "good nutrition can lead to less ill health" and "forest foods contain nutrients which are important for eye sight". These findings are in line with other literature, which showed that having a positive perception towards health and nutrition benefits of indigenous and traditional foods, was a driving force for a person to improve his/her healthful and nutrition knowledge, practices and behaviours (Chen et al., 2003).

A positive perception is the driving force of a correct practice and use of certain concepts (Sharma et al., 2008). Thus, positive perceptions appear to be important factors that 
drive correct nutrition practices. In this sense, targeted community or village nutrition education programmes aimed to improve perceptions of rural forest dependent communities need to be emphasized to policy makers, health and forestry community workers and development practitioners.

\section{CONCLUSION}

A number of factors, including; age, education and marital status, perceptions towards nutritional and health benefits of forest foods influenced the consumption of forest foods.

Initiatives aimed at promoting consumption of forest foods should, as a basic necessity, aim equipping communities with information regarding the nutrition and health benefits of consuming forest foods. The success of such initiatives would most likely be influenced by a number of sociodemographic factors such as education, sex, age and marriage status. These factors should be taken into consideration when planning forest foods promotion interventions. Nutrition education materials on the health benefits of forest foods need to be developed and disseminated to the forest-dwelling population. In addition, studies relating nutrition status outcomes and links to forest food intake need to be scaled up to inform future interventions. Fundamentally, it is vital to adopt strategic policies and legislation that are sensitive to the nutritional health benefits of forest foods in order to conserve the bio-diversity, nutrition and development benefits that comes along with their ecosystem.

\section{ACKNOWLEDGMENT}

This study was carried out with funding from the Congo Basin Forest Fund (CBFF) and donors to the CGIAR Research Programme on Forests, Trees and Agroforestry, through grants to Bioversity International. Aside from their funding, the CBFF was not involved in producing the scientific results nor in developing or submitting the article. Co- funding and additional support was provided by IRAD, Cameroon. We thank the concessions and personnel of FIPCAM and SCTB, and the communities of Meyos, Ndembo, Ngone and Nkolbikon for their support to our research.

\section{REFERENCES}

African Plant Database (APD), 2013. Conservatoire et Jardin botaniques de la Ville de Genève and South African National Biodiversity Institute, Pretoria, Retrieved $1^{\text {st }}$ November 2016 from http://www.villege.ch/musinfo/bd/cjb/africa 2013.

Akpavi, S., Batawila, K., Wala, K., KossiTitrikou, K., Amouzou, K., Kokou, K., Chango, A., Butare, I. and Akpagana, K. 2008. Sociocultural factors influencing the availability and the consumption of food plants in Togo', Paper presented to Theme 1: Just Famine Food? What Contributions can Underutilised Plants Make to Food Security? at the International Symposium on Underutilised Plants for Food, Nutrition, Income and Sustainable Development, Arusha, Tanzania, 3-7 March 2008.

Awono, A., Djouguep, A., Zapfack, L. and Ndoye, O. 2009. The potential of Irvingia gabonensis: Can it contribute to the improvement of the livelihoods of producers in Southern Cameroon? International Journal of Social Forestry 2(1):67-85.

Becquey, E., Capon, G. and Martin-Prével, Y. 2009. Validation of dietary diversity as a measure of the micronutrient adequacy of women's diets: Results from Ouagadougou (Burkina Faso). Washington, DC: FANTA2 at FHI 360.

Blaney, S., Beaudry, M. and Latham, M. 2009. Contribution of natural resources to nutritional status in a protected area of Gabon. Food \& Nutrition Bulletin 30(1): 49-62.

Boedecker, J., Termote, C., Assogbadjo, A.C., VanDamme, P. and Lachat, C. 2014. Dietary contribution of wild edible plants to women's diets in the buffer zone around 
the Lama forest, Benin an underutilized potential. Food Security 6:833-849. DOI 10.1007/s12571-014-0396-7.

Burdock, G.A., Carabin, I.G. and Crincoli, C.M. 2009. Safety assessment of kola nut extract as a food ingredient. Food and Chemical Toxicology 47(8):1725-1732.

Cameroon Demographic and Health Survey (CDHS). 2011. National institute of statistics Cameroon and ORC Macro International, Inc. Calverton, Maryland, USA 2011.

Cerutti, P.O. and Tacconi, L. 2006. Forests, illegality, and livelihoods in Cameroon. Working Paper No. 35. CIFOR, Bogor. p. 28.

Chao, W. 2012. Forest Peoples: Numbers across the world. Forest Peoples Programme. United Kingdom.

Chen, M.X., He, W., Fu, Z.Y. and Wang, Y. 2003. Multiple factors analysis on malnutrition of children and under five in different patterns in China in 2000. Journal of Hygiene Research 3:249-253.

Dweba, T.P. and Mearns, M.A. 2011. Conserving indigenous knowledge as the key to the current and future use of traditional vegetables. International Journal of Information Management 31:564-571.

Ejiofor, M.A.N, Onwuboker, S.N. and Okafor, J.C. 1987. Developing improved method of processing and utilization of kernel of Irvingia gabonensis. International Tree Crops Journal 4:283-290.

Enviro Consulting 2009. E'tude d'impact environnemental des activite's d'exploitation de laconcession forestie 're n81050 (UFA 09017 and 09018) situe'e dans les arrondissements d'Ebolowa II, Biwongbulu et de Mvangande' partement de Lamvila, re'gion du sud [Environmental impact assessment of loggingactivties in concession n81050 (UFA 09017 and09018) in the districts Ebolowa II, Biwongbulu and Mvangan, department of Lamvila, SouthRegion]. Yaounde': FIPCAM .
FAO/WFP/IFAD, 2014. The state of food insecurity in the world. Economic growth is necessary but not sufficient to accelerate reduction of hunger and malnutrition. Rome, FAO http://www.fao.org/docrep/ 016/i3027e/i3027e.pdf Accessed 31 $1^{\text {st }}$ January 2015.

Fisher, L.D. 1998. Self-designing clinical trials. Statistics in Medicine 17:1551-1562.

Frison, E.A., Smith, I.F., Johns, T., Cherfas, J. and Eyzaguirre, P.B. 2006. Agricultural biodiversity, nutrition and health: Making a difference to hunger and nutrition in the developing world. Food Nutrition Bulletin 27(2):167-179.

Fungo, R. 2016. Potential of the Congo basin forest foods, to address food and nutrition security. EC Nutrition 6(3):100-101.

Fungo, R., Muyonga, J., Kabahenda, M., Kaaya, A., Okia, C., Donn, P., Tchtat, M., Tchingsabe, O., Tieguhong, J.C., Loo, J. and Snook, L. 2016a. Contribution of forest foods to women's nutrient intake and household food security, in the biodiversityrich Cameroonian forests. Public Health Nutrition (17):3185-3196. doi:10.1017/ S1368980016001324

Fungo, R., Muyonga, J.H., Kabahenda, M., Okia, C.A and Snook, L. 2016b. Factors influencing consumption of nutrient rich forest foods in rural Cameroon. Appetite 97(1):176-184.

Fungo, R., Muyonga, J., Kaaya, A., Okia, C., Tieguhong, J.C. and Baidu-Forson, J.J. 2015. Nutrient quality and bioactive compounds of Baillonella toxisperma, Trichoschypa abut and Pentaclethra macrophylla from Cameroon. Journal of Food Science and Nutrition 3(4): 292-301

Haddad, L. 2003. Redirecting the nutrition transition: what can food policy do? Development Policy Review 21: 599- 614. Hamawa, Y. 2013. Wild edible plants used by Guiziga people of far north region of Cameroon. International Journal of Medicinal and Aromatic Plants 3(2):136143. 
Hart, T.G.B. and Vorster, H.J. 2006. The importance of indigenous knowledge in reducing poverty of rural agrarian households. Final Report, Department of Science and Technology, South Africa, May 2006.

International Food Policy Research Institute (IFPRI), 2014. Global Nutrition Report 2014: Actions and Accountability to Accelerate the World's Progress on Nutrition. Washington, DC., USA.

Keegan, W.F. 1986. The optimal foraging analysis of horticultural production. American Anthropologist 88 (1):92-107.

Keller, G.B., Mndiga, H. and Maass, B. 2006. Diversity and genetic erosion of traditional vegetables in Tanzania from the farmer's point of view. Plant Genetic Resources 3: 400-413.

Kimiywe, J., Waudo, J., Mbithe, D. and Maundu, P. 2007. Utilization and medicinal value of indigenous leafy vegetables consumed in urban and peri-urban Nairobi. African Journal of Food, Agriculture Nutrition and Development 7 (4):14-21.

Levang, P., Lescuyer, G., Noumbissi, D., Dehu, C. and Broussolle, L. 2014. Does gathering really pay? Case studies from forest areas of the East and South regions of Cameroon. Forests, Trees and Livelihoods DOI: 10.1080/14728028. 2014.1000980

Maundu, P.M. 1996. Utilization and conservation status of wild food plants in Kenya. In The biodiversity of African plants. Proceedings of the XIV AETFAT Congress. 22-27 August 1994, Wageningen, The Netherlands. Van der Maesen, L. J. G., van der Burg, X. M. and van Medenbach de Rooy, J. M. Dordrecht, the Netherlands: Kluwer Academic Publishers. pp. 678-683.

Medinof, 2004. Plan d'ame'nagement des concessions N81046/UFA10046 et N81059/UFA 10059 et 10060 [Management plans of concessions N81046/UFA10046 and N81059/UFA 10059 and 10060]. SCTB.
Nasi, R., Taber, A., and Vliet, N.V. 2011. Empty forests, empty stomachs? Bushmeat and livelihoods in the Congo and Amazon Basins. International Forestry Review 13(3):355-368.

Noutcheu, R., Snook, L.K., Tchatat, M., Taedoumg, H., Tchingsabe, $O$. and Tieguhong, J.C. 2016. Do logging concessions decrease the availability to villagers of foods from timber trees? A quantitative analysis for Moabi (Baillonella toxisperma), Sapelli (Entandrophragma cylindricum) and Tali (Erythrophleum suaveolens) in Cameroon. Forest Ecology and Management 381: 279-288.

Onarheim, K.H., Iversen, J.H., and Bloom, D.E. 2016. Economic benefits of investing in women's health: a systematic review. PloS One 11(3): 0150120.

Oniang'o, R.K., Mutuku, J.M. and Malaba, S.J. 2003. Contemporary African food habits and their nutritional and health implications. Asia Pacific Journal of Clinical Nutrition 12(3):231-236.

Parsons, N. 1993. A New History of Southern Africa ( $\left.2^{\text {nd }} E d n.\right)$ Mac-Millan, London. 349pp.

Pelto, G.H., Santos, I., Goncalves, H., Victora C., Martines, J. and Habicht, J.P. 2004. Nutrition counselling training changes physician behaviour and improves caregiver knowledge acquisition. Journal of Nutrition 134:357-362.

Penafiel, D., Lachat, C., Espinel, R., VanDamme, P. and Kolsteren, P. 2011. Systematic review on the contributions of edible plant and animal biodiversity to human diets. EcoHealth 8(3):381-399.

Pingali, P. 2007. Westernization of Asian diets and the transformation of food systems: Implications for research and policy. Food Policy 32:281-298.

Powell, B., Maundu, P., Kuhnlein, H. and Johns, T. 2013. Wild foods from farm and forest in the East Usambara Mountains, Tanzania. Ecology of Food and Nutrition 52:451-478. 
Rensberg, JansenVan, W.S., Venter, S.L., Netshiluvhi, R., VanDen, H,E., Vorster, H.J. and DeRonde, J.A. 2004. Role of indigenous leafy vegetables in combating hunger and malnutrition. South African Journal of Botany 70:52-59.

Serra-Majem, L., Pastor-Ferrer, M.C., Castell, C., Ribas-Barba, L., Roma'n-Viñas, B., Ribera, F.L., Plasencia, A. and Salleras, L, 2007. Trends in blood lipids and fat soluble vitamins in Catalonia, Spain (1992-2003). Public Health Nutrition 10(11A):13791388.

Sharma, S.V., Gernand, A.D. and Day, R.S. 2008. Nutrition knowledge predicts eating behavior of all food groups except fruits and vegetables among adults in the Paso del Norte region: Que' Sabrosa Vida. Journal of Nutrition Education Behaviour 40:361-368.
Tabuti, J.R.S., Dhillion, S.S. and Lye, K.A. 2004. The status of wild food plants in Bulamogi County, Uganda. International Journal of Food Sciences and Nutrition 55: 485-498.

Tacconi, L., Boscolo, M. and Brack, D. 2003. National and international policies to control illegal forest activities. Report for the Ministry of Foreign Affairs, Government of Japan. CIFOR, Bogor, Indonesia.

Termote, C., BwamaMeyi, M., Dhed'a Djailo, B., Huybregts, L., Lachat, C., Kolsteren, P. and VanDamme, P. 2012. A biodiverse rich environment does not contribute to a better diet: a case study from DR Congo. PLoS ONE 7(1):e30533.

World Medical Association Declaration of Helsinki, 2001. Ethical Principles for Medical Research Involving Human Subjects. Bulletin of the World Health Organization 79(4):373-374. 